\title{
Solvent-Free Synthesis of the Smallest Rotaxane Prepared to Date**
}

\author{
Chi-Chieh Hsu, Nai-Chia Chen, Chien-Chen Lai, Yi-Hung Liu, Shie-Ming Peng, and Sheng- \\ Hsien Chiu*
}

[2]Rotaxanes-supermolecules comprising interlocked macrocyclic and dumbbell-shaped components-are fascinating materials for the construction of molecular devices because of the machinelike movement of their constituent parts. ${ }^{[1]}$ The development of efficient, convenient, and environmentally friendly methods for the synthesis of these functional interlocked molecules has progressed tremendously in the past decade. ${ }^{[2]}$ We became interested, however, in answering the following fundamental question: What is the smallest [2]rotaxane that can be synthesized, either in terms of molecular weight or the number of constituent atoms? We identified the crown ether/secondary dialkylammonium ion pair, which can be simplified into a few repeating $\mathrm{CH}_{2} \mathrm{CH}_{2} \mathrm{O}$ units that encircle a threadlike component as small as a dimethylammonium $\left(\mathrm{CH}_{3} \mathrm{NH}_{2}{ }^{+} \mathrm{CH}_{3}\right)$ ion, as the simplest and smallest recognition system for preparing [2]rotaxanes. Herein, we report a new and efficient solvent-free reaction which involves ball-milling of the [2]pseudorotaxane formed from dipropargylammonium tetrafluoroborate and the crown ether [21]crown-7 (21C7) on $\mathrm{SiO}_{2}$ with 1,2,4,5-tetrazine. This led to the isolation in high yield $(81 \%)$ of the smallest [2]rotaxane reported to date (Scheme 1).

Although it has been postulated for some time that macrocycles possessing 21 or more atoms in their ring will be able to accommodate an alkyl chain, ${ }^{[3]}$ it was only recently reported that a secondary dialkylammonium ion could be threaded through a 21-membered ring macrocycle, namely benzo[21]crown-7 (B21C7). ${ }^{[4]}$ In addition, a phenyl group can act as the stopper that prevents the unthreading of the interlocked ring-shaped and linear components when this small macrocycle is used. We proposed that Diels-Alder reactions of 1,2,4,5-tetrazine ${ }^{[5]}$ with the terminal alkyne units of a 21C7-based [2]pseudorotaxane would produce pyridazine

[*] C.-C. Hsu, N.-C. Chen, Y.-H. Liu, Prof. S.-M. Peng, Prof. S.-H. Chiu Department of Chemistry, National Taiwan University

No. 1, Sec. 4, Roosevelt Road, Taipei (Taiwan, ROC)

Fax: $(+886)$ 2-3366-1677

E-mail: shchiu@ntu.edu.tw

Homepage: http://www.ch.ntu.edu.tw/english/efaculty/people/ chiu-eng.html

Prof. C.-C. Lai

Institute of Molecular Biology, National Chung Hsing University and Department of Medical Cenetics

China Medical University Hospital

Taichung (Taiwan, ROC)

[**: We thank Dr. Peter T. Glink for helpful discussions and the National Science Council (Taiwan) for financial support (NSC-95-2113M-002016-MY3).

() Supporting information for this article is available on the WWWW under http://dx.doi.org/10.1002/anie.200803056.

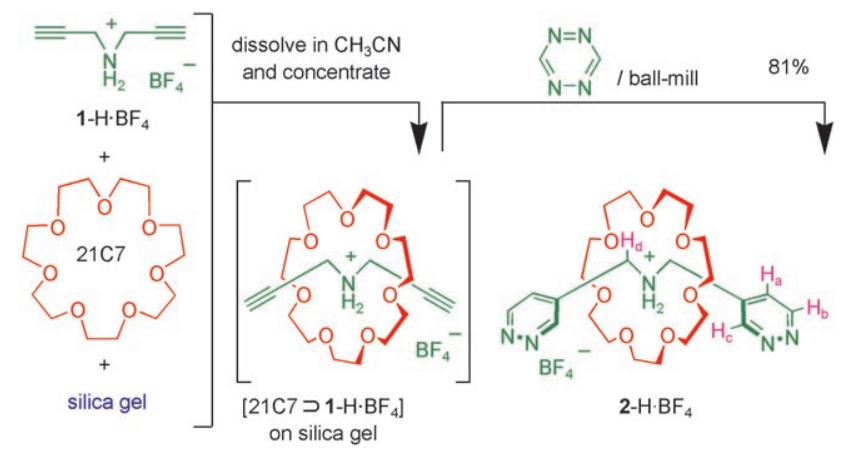

Scheme 1.

end groups, which are slightly less bulky than phenyl groups, and might also function as stoppers in a 21C7-containing [2]rotaxane. We chose the dipropargylammonium ion $\left(\mathbf{1}-\mathrm{H}^{+}\right)$ as the alkyne-terminated linear component in the small [2]pseudorotaxane precursor, expecting its small $\mathrm{CH}_{2} \mathrm{NH}_{2}{ }^{+} \mathrm{CH}_{2}$ unit to reside within the cavity of the crown ether 21C7, stabilized through $\mathrm{N}^{+}-\mathrm{H} \cdots \mathrm{O}$ and $\mathrm{C}-\mathrm{H} \cdots \mathrm{O}$ hydrogen bonds. The alkyne termini are available for functionalization (Scheme 1) through Diels-Alder reactions with 1,2,4,5-tetrazine to generate small, but nevertheless sufficiently bulky, pyridazine rings for stoppering the pseudorotaxanes under solvent-free conditions.

The ${ }^{1} \mathrm{H}$ NMR spectrum (Figure $1 \mathrm{~b}$ ) of an equimolar (5 mM) mixture of $21 \mathrm{C} 7$ and $\mathbf{1}-\mathrm{H} \cdot \mathrm{BF}_{4}$ in $\mathrm{CD}_{3} \mathrm{CN}$ at room temperature shows the chemical shifts of the protons of the complex are significantly different from those of its free components. The appearance of broad signals for both the free and complexed thread $1-\mathrm{H} \cdot \mathrm{BF}_{4}$ in the ${ }^{1} \mathrm{H}$ NMR spectrum (Figure 1c) of a 1:2 molar ratio mixture of $21 \mathrm{C} 7$ and $\mathbf{1}-\mathrm{H} \cdot \mathrm{BF}_{4}$ in $\mathrm{CD}_{3} \mathrm{CN}$ suggested that the rates of exchange during the complexation and decomplexation processes were slow on the ${ }^{1} \mathrm{H}$ NMR spectroscopic timescale at $400 \mathrm{MHz}$ under these conditions, but not sufficiently slow to provide the sharp signals required to obtain an accurate value for the association constant through the single-point method. ${ }^{[6]}$ Instead, we used isothermal titration calorimetry (ITC) ${ }^{[7]}$ to determine an association constant of $(14000 \pm 1300) \mathrm{M}^{-1}$ for the formation of the [2]pseudorotaxane from $21 \mathrm{C} 7$ and $\mathbf{1}-\mathrm{H} \cdot \mathrm{BF}_{4}$ in $\mathrm{CH}_{3} \mathrm{CN}$ at $25^{\circ} \mathrm{C} \cdot{ }^{[8]}$

Concentration of an equimolar solution of the macrocycle $21 \mathrm{C} 7$ and the threadlike ion $\mathbf{1}-\mathrm{H} \cdot \mathrm{BF}_{4}$ gave a sticky liquid, which we presumed to contain predominately the [2]pseudorotaxane $\left[(21 \mathrm{C} 7 \supset \mathbf{1}-\mathrm{H}) \cdot \mathrm{BF}_{4}\right] \cdot{ }^{[9]}$ To facilitate ball-milling in the solid state, we added silica gel to an equimolar solution of $21 \mathrm{C} 7$ and $1-\mathrm{H} \cdot \mathrm{BF}_{4}$ in $\mathrm{CH}_{3} \mathrm{CN}$ and evaporated the solvent, thereby anticipating the solid support to be coated with the 


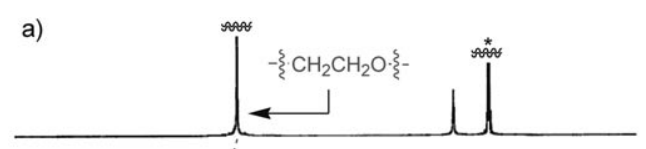

b)
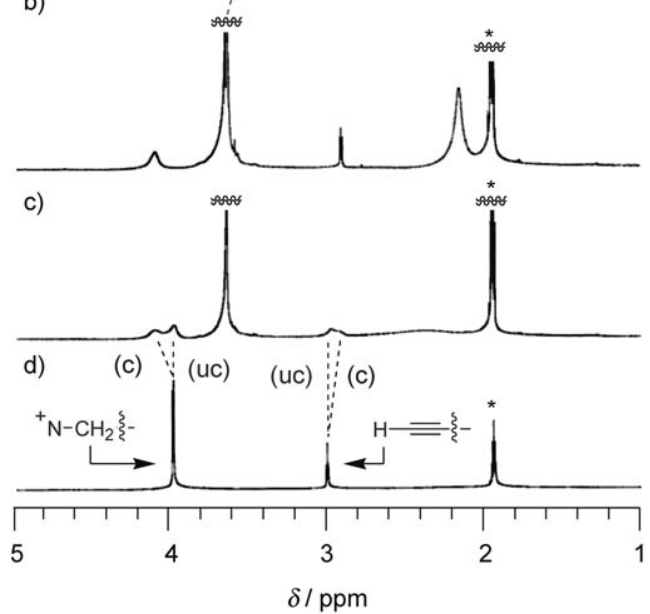

Figure 1. ${ }^{1} \mathrm{H} \mathrm{NMR}$ spectra $\left(400 \mathrm{MHz}, \mathrm{CD}_{3} \mathrm{CN}, 298 \mathrm{~K}\right)$ of a) $21 \mathrm{C}$, b) an equimolar mixture of $21 \mathrm{C7}$ and $\left.1-\mathrm{H} \cdot \mathrm{BF}_{4}(5 \mathrm{~mm}), \mathrm{c}\right)$ a mixture of $21 \mathrm{C7}$ $(5 \mathrm{~mm})$ and $\mathbf{1}-\mathrm{H} \cdot \mathrm{BF}_{4}(10 \mathrm{~mm})$, and d) $1-\mathrm{H} \cdot \mathrm{BF}_{4}$. (c) = complexed and (uc) $=$ uncomplexed states of the components.

[2]pseudorotaxane. Grinding the solid mixture of the $\left[(21 \mathrm{C} 7 \supset \mathbf{1}-\mathrm{H}) \cdot \mathrm{BF}_{4}\right]$-coated silica gel and 1,2,4,5-tetrazine for $1 \mathrm{~h}$, followed by heating the resulting well-mixed solid at $353 \mathrm{~K}$ for $12 \mathrm{~h}$, gave the [2] rotaxane $\mathbf{2}-\mathrm{H} \cdot \mathrm{BF}_{4}$ in $30 \%$ yield. The presence of red crystals of 1,2,4,5-tetrazine on the neck of the reaction flask suggested that its facile sublimation was responsible for the low yield of the reaction. Thus, to avoid loss of 1,2,4,5-tetrazine during the heating process and thereby increase the yield of this small [2]rotaxane, we turned our attention to performing the stoppering reactions under solid-to-solid ball-milling conditions of a 1:2.2 mixture of the [2]pseudorotaxane complex [(21C7つ1-H) $\cdot \mathrm{BF}_{4}$ ] on $\mathrm{SiO}_{2}$ and 1,2,4,5-tetrazine at ambient temperature. To monitor this process, we dissolved portions of the solid reaction mixture in $\mathrm{CD}_{3} \mathrm{CN}$, filtered off the $\mathrm{SiO}_{2}$, and then recorded ${ }^{1} \mathrm{H} \mathrm{NMR}$ spectra. Over time, a new set of signals appeared with increasing intensity (Figure 2). After ball-milling for $9 \mathrm{~h}$, these signals were predominant (Figure $2 \mathrm{f}$ ); at this point, we extracted the product and obtained the [2] rotaxane $2-\mathrm{H} \cdot \mathrm{BF}_{4}$ in $81 \%$ yield. ${ }^{[10]}$ The reaction between $21 \mathrm{C} 7$, the threadlike salt $\mathbf{1}-\mathrm{H} \cdot \mathrm{BF}_{4}$, and 1,2,4,5-tetrazine (20:20:44 mM) did not proceed as efficiently in solution $\left(\mathrm{CD}_{3} \mathrm{CN}, 333 \mathrm{~K}\right)$ as it did through ball-milling; ${ }^{1} \mathrm{H}$ NMR spectroscopy showed that the reaction was relatively slow and produced a complicated mixture after $60 \mathrm{~h}$ (see the Supporting Information).

We obtained single crystals suitable for X-ray crystallography after liquid diffusion of isopropyl ether into a solution of the [2]rotaxane $\mathbf{2}-\mathrm{H} \cdot \mathrm{BF}_{4}$ in methanol. ${ }^{[1,12]}$ The solid-state structure in Figure 3 reveals the expected [2]rotaxane geometry, in which the threadlike unit is penetrated through the 21membered ring, with the $\mathrm{CH}_{2} \mathrm{NH}_{2}^{+}$protons hydrogen bonded to the oxygen atoms of the macrocyclic unit.

The ${ }^{1} \mathrm{H}$ NMR spectrum of a mixture of the [2]rotaxane 2$\mathrm{H} \cdot \mathrm{BF}_{4}$ and threadlike salt $\mathbf{1}-\mathrm{H} \cdot \mathrm{BF}_{4}$ in $\mathrm{CD}_{3} \mathrm{CN}(5 \mathrm{~mm}: 5 \mathrm{~mm})$ at

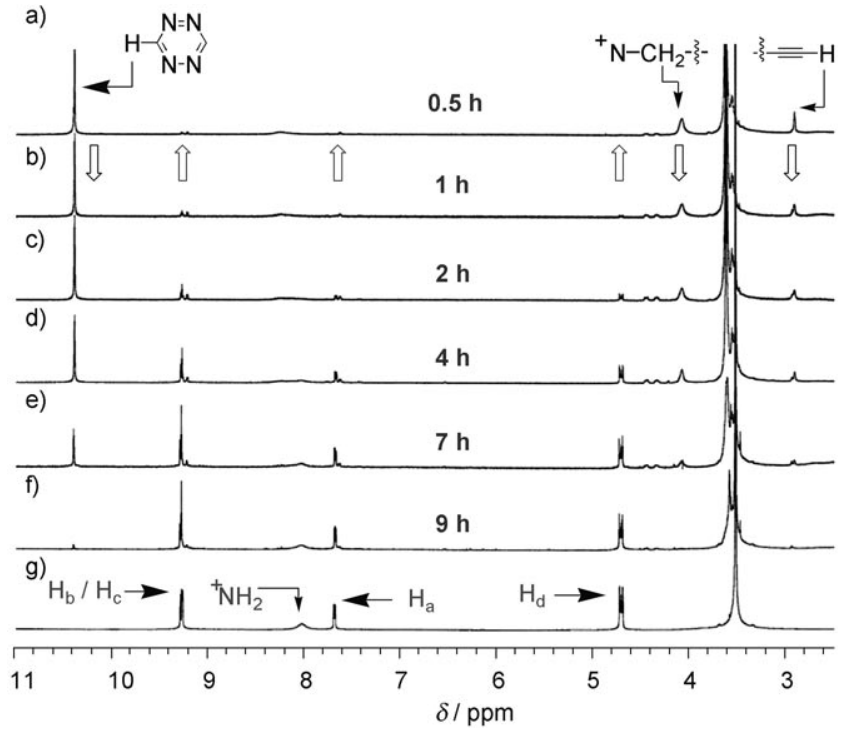

Figure 2. Partial ${ }^{1} \mathrm{H}$ NMR spectra $\left(400 \mathrm{MHz}, \mathrm{CD}_{3} \mathrm{CN}, 298 \mathrm{~K}\right)$ that show the formation of the [2] rotaxane $2-\mathrm{H} \cdot \mathrm{BF}_{4}$ from the pseudorotaxane [(21C7つ1-H) $\left.\cdot \mathrm{BF}_{4}\right]$ after solid-state ball-milling for a) 0.5, b) 1, c) 2 , d) 4 , e) 7 , and f) $9 \mathrm{~h}$; g) spectrum of purified $2-\mathrm{H} \cdot \mathrm{BF}_{4}$. a)

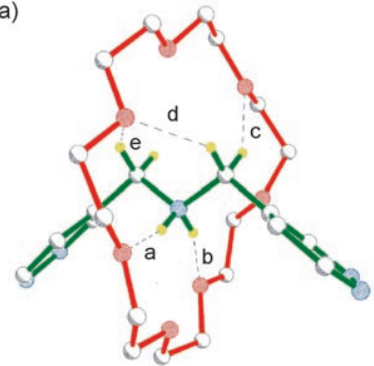

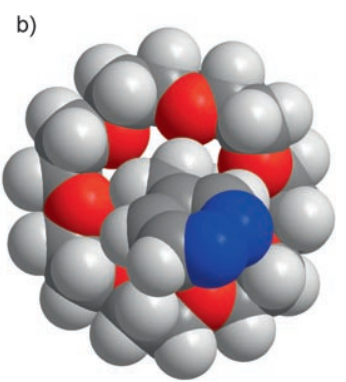

Figure 3. a) Ball-and-stick (side view) and b) space-filling (top view) representations of the solid-state structure of the [2] rotaxane $2-\mathrm{H}^{+}$. Atom labels: $\mathrm{C}$, gray; $\mathrm{H}$, yellow; $\mathrm{O}$, orange; $\mathrm{N}$, blue. Hydrogen-bond geometries, $\mathrm{X} \cdots \mathrm{O}, \mathrm{H} \cdots \mathrm{O}[\AA]$, and $\mathrm{X}-\mathrm{H} \cdots \mathrm{O}\left[{ }^{\circ}\right]$ : a) $2.86,1.99,160.6$; b) $2.89,2.01,163.0$; c) $3.19,2.28,154.9$; d) $3.23,2.38,145.2$; e) 3.44 , $2.67,136.0$

$298 \mathrm{~K}$ (Figure $4 \mathrm{~b}$ ) corresponds to the superimposition of the two spectra (Figure $4 \mathrm{a}, \mathrm{c}$ ) of the two separate components, which suggests that no free $21 \mathrm{C} 7$ was present in the solution and supports the constitutional authenticity and integrity of the [2] rotaxane $\mathbf{2}-\mathrm{H} \cdot \mathrm{BF}_{4}$. We detected no signals for the free components in the ${ }^{1} \mathrm{H}$ NMR spectrum (see the Supporting Information) obtained after heating a solution of the [2]rotaxane $2-\mathrm{H} \cdot \mathrm{BF}_{4}$ in $\mathrm{CD}_{3} \mathrm{SOCD}_{3}$ at $323 \mathrm{~K}$ for $2 \mathrm{~h}$, thus confirming the interlocked nature of the two components.

To the best of our knowledge, $\mathbf{2}-\mathrm{H} \cdot \mathrm{BF}_{4}$ is the smallest [2]rotaxane reported to date. The cationic portion of the rotaxane $\left(\mathrm{C}_{24} \mathrm{H}_{40} \mathrm{O}_{7} \mathrm{~N}_{5}\right)$ comprises only 76 atoms (27 and 49 for the dumbbell-shaped and macrocyclic components, respectively); its molecular weight is $510 \mathrm{Da}$. In comparison, two macrocycles used frequently to create interlocked molecules, cyclobis(paraquat- $p$-phenylene $)^{4+[13]}$ and the macrocycle developed by Leigh and co-workers, ${ }^{[14]}$ have 72 and 68 
a)

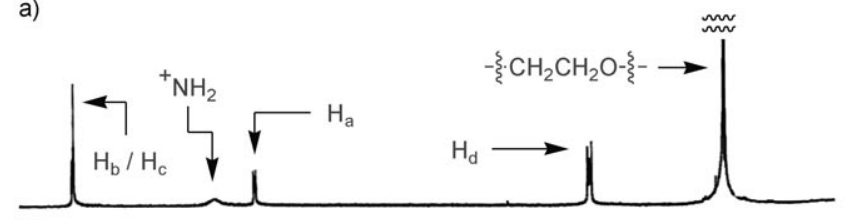

b)

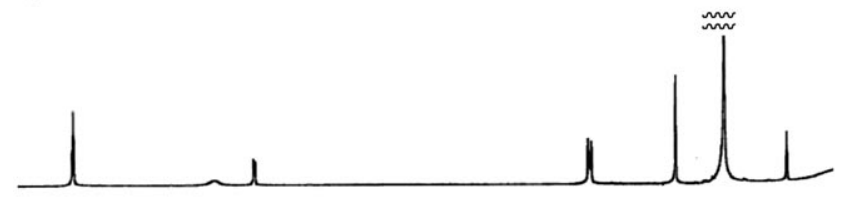

c)

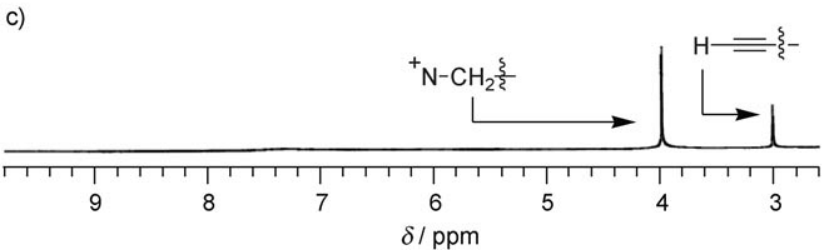

Figure 4. ' $\mathrm{H}$ NMR spectra (400 MHz, $\mathrm{CD}_{3} \mathrm{CN}, 298 \mathrm{~K}$ ) of a) [2]rotaxane $2-\mathrm{H} \cdot \mathrm{BF}_{4}$; b) an equimolar mixture of $2-\mathrm{H} \cdot \mathrm{BF}_{4}$ and the threadlike salt $1-\mathrm{H} \cdot \mathrm{BF}_{4}$ (both $5 \mathrm{~mm}$ ), and c) $1-\mathrm{H} \cdot \mathrm{BF}_{4}$.

atoms, respectively, and molecular masses of 520 and $532 \mathrm{Da}$, respectively, making them heavier than the [2] rotaxane $2-\mathrm{H}^{+}$ even in the absence of guest molecules. Two other simple molecular recognition systems, dibenzo[24]crown-8/1,2-bis(pyridinium)ethane $^{2+[15]}$ and bis- $p$-xylyl[26]crown-6/Nmethyl-4-methylpyridinium ${ }^{+[16]}$ have 92 and 80 atoms, respectively, and molecular masses of 634 and $524 \mathrm{Da}$, respectively, which suggests that their interlocked versions would certainly be larger and heavier than the [2] rotaxane $2-\mathrm{H}^{+}$. We will test our knowledge of supramolecular chemistry and synthetic skills by continuing the search for the world's smallest rotaxane. Maybe a macrocycle containing less than 21 atoms will be capable of threading guests $?^{[17]}$ Maybe an isopropyl group, which is lighter and contains fewer atoms than the pyridazine ring, could act as a stopper? Like athletes striving to achieve Olympic ideals-citius (swifter), altius (higher), fortius (stronger) - chemists have a new challenge when it comes to synthesizing [2] rotaxanes: minimus (smallest)!

\section{Experimental Section}

General method for the ball-milling process: Ball-milling was performed using a Retsch MM 200 swing-mill, containing two $5 \mathrm{~mL}$ stainless steel cells and two stainless steel balls (diameter: $7 \mathrm{~mm}$ ); the mill was operated at a frequency of $22.5 \mathrm{~Hz}$ at room temperature.

[2]Rotaxane $2-\mathrm{H}^{-} \mathrm{BF}_{4}$ : Silica gel $(135 \mathrm{mg})$ was added to a solution of $21 \mathrm{C} 7(86 \mathrm{mg}, 280 \mu \mathrm{mol})$ and the threadlike salt $\mathbf{1}-\mathrm{H} \cdot \mathrm{BF}_{4}(50 \mathrm{mg}$, $280 \mu \mathrm{mol})$ in $\mathrm{CH}_{3} \mathrm{CN}(5 \mathrm{~mL})$. The solvent was evaporated under reduced pressure to afford a white solid, which was mixed with 1,2,4,5-tetrazine $(50 \mathrm{mg}, 610 \mu \mathrm{mol})$ and ball-milled at room temperature for $9 \mathrm{~h}$. The resulting solid was washed with $\mathrm{MeCN}(25 \mathrm{~mL})$ and then the organic solution was concentrated to afford a solid, which was dissolved in $\mathrm{CH}_{2} \mathrm{Cl}_{2}(20 \mathrm{~mL})$ and extracted with $\mathrm{H}_{2} \mathrm{O}(3 \times 20 \mathrm{~mL})$. The aqueous layer was collected and concentrated to afford the [2]rotaxane 2- $\mathrm{H} \cdot \mathrm{BF}_{4}$ as a brown solid $(134 \mathrm{mg}, 81 \%)$. M.p. 148 $149^{\circ} \mathrm{C} ;{ }^{1} \mathrm{H}$ NMR $\left(400 \mathrm{MHz}, \mathrm{CD}_{3} \mathrm{CN}\right): \delta=3.52(\mathrm{~s}, 28 \mathrm{H}), 4.72(\mathrm{t}, J=$ $6 \mathrm{~Hz}, 4 \mathrm{H}), 7.69(\mathrm{dd}, J=5,2 \mathrm{~Hz}, 2 \mathrm{H}), 7.95-8.15(\mathrm{br}, 2 \mathrm{H}), 9.26-$ $9.31 \mathrm{ppm}(\mathrm{m}, 4 \mathrm{H}) ;{ }^{13} \mathrm{C}$ NMR $\left(100 \mathrm{~Hz}, \mathrm{CD}_{3} \mathrm{CN}\right): \delta=49.2,71.7,128.5$,
132.2, 152.4, $153.2 \mathrm{ppm}$; HRMS (ESI): $\mathrm{m} / \mathrm{z}$ calcd for $[\mathbf{2}-\mathrm{H}]^{+}$ $\left(\mathrm{C}_{24} \mathrm{H}_{40} \mathrm{~N}_{5} \mathrm{O}_{7}\right): 510.2922$; found: 510.2928 .

Received: June 25, 2008

Published online: August 28, 2008

Keywords: Diels-Alder reaction - host-guest systems . pyridazine $\cdot$ rotaxanes . solvent-free synthesis

[1] a) Molecular Electronics: Science and Technology (Eds.: A. Aviram, M. Ratner), New York Academy of Sciences, New York, 1998; b) H. Yu, Y. Luo, K. Beverly, J. F. Stoddart, H.-R. Tseng, J. R. Heath, Angew. Chem. 2003, 115, 5884-5889; Angew. Chem. Int. Ed. 2003, 42, 5706-5711; c) J. W. Choi, A. H. Flood, D. W. Steuerman, S. Nygaard, A. B. Braunschweig, N. N. P. Moonen, B. W. Laursen, Y. Luo, E. DeIonno, A. J. Peters, J. O. Jeppesen, K. Xu, J. F. Stoddart, J. R. Heath, Chem. Eur. J. 2006, 12, 261 -279; d) J. E. Green, J. W. Choi, A. Boukai, Y. Bunimovich, E. Johnston-Halperin, E. DeIonno, Y. Luo, B. A. Sheriff, K. $\mathrm{Xu}$, Y. S. Shin, H.-R. Tseng, J. F. Stoddart, J. R. Heath, Nature 2007, 445, 414-417.

[2] For reviews, see: a) M. C. T. Fyfe, J. F. Stoddart, Adv. Supramol. Chem. 1999, 5, 1-53; b) S. J. Rowan, S. J. Cantrill, G. R. L. Cousins, J. K. M. Sanders, J. F. Stoddart, Angew. Chem. 2002, 114, 938-993; Angew. Chem. Int. Ed. 2002, 41, 898-952; c) E. R. Kay, D. A. Leigh, Top. Curr. Chem. 2005, 262, $133-$ 177; d) F. Huang, H. W. Gibson, Prog. Polym. Sci. 2005, 30, 982-1018; e) J. Berná, G. Bottari, D. A. Leigh, E. M. Perez, Pure Appl. Chem. 2007, 79, 39-54; f) B. Champin, P. Mobian, J.P. Sauvage, Chem. Soc. Rev. 2007, 36, 358-366; g) K. E. Griffiths, J. F. Stoddart, Pure Appl. Chem. 2008, 80, 485-506.

[3] a) I. T. Harrison, J. Chem. Soc. Chem. Commun. 1972, 231-232; b) G. Schill, Catenanes, Rotaxanes and Knots, Academic Press, New York, 1971; c) G. Schill, W. Beckmann, W. Vetter, Chem. Ber. 1980, 113, 941-954; d) G. Schill, W. Beckmann, N. Schweickert, H. Fritz, Chem. Ber. 1986, 119, 2647-2655.

[4] C. Zhang, S. Li, J. Zhang, K. Zhu, N. Li, F. Huang, Org. Lett. 2007, 9, $5553-5556$.

[5] J. Sauer, D. K. Heldmann, J. Hetzenegger, J. Krauthan, H. Sichert, J. Schuster, Eur. J. Org. Chem. 1998, 2885-2896.

[6] For a description of the single-point method, see: a) P. R. Ashton, E. J. T. Chrystal, P. T. Glink, S. Menzer, C. Schiavo, N. Spencer, J. F. Stoddart, P. A. Tasker, A. J. P. White, D. J. Williams, Chem. Eur. J. 1996, 2, 709-728; b) P. R. Ashton, M. C. T. Fyfe, S. K. Hickingbottom, J. F. Stoddart, A. J. P. White, D. J. Williams, J. Chem. Soc. Perkin Trans. 2 1998, 2117-2124.

[7] For examples of the use of ITC methods to obtain association constants for pseudorotaxane complexes, see: a) A. B. Braunschweig, C. M. Ronconi, J.-Y. Han, F. Arico, S. J. Cantrill, J. F. Stoddart, S. I. Khan, A. J. P. White, D. J. Williams, Eur. J. Org. Chem. 2006, 8, 1857-1866; b) Y. Liu, C.-J. Li, H.-Y. Zhang, L.-H. Wang, X.-Y. Li, Eur. J. Org. Chem. 2007, 4510-4516.

[8] The values of binding stoichiometry $(N)$, entropy $\left(\Delta S^{\circ}\right)$, and enthalpy $\left(\Delta H^{\circ}\right)$ for the complexation were determined to be $(1.05 \pm 0.02), \quad(-2.51 \pm 0.40) \mathrm{cal} \mathrm{mol}^{-1} \mathrm{~K}^{-1}, \quad$ and $\quad(-6420 \pm$ 120) $\mathrm{cal} \mathrm{mol}^{-1}$, respectively, based on the mean results of three independent titrations. The errors are reported as standard deviations from the mean.

[9] A similar method has been used to generate pseudorotaxanes as solids for the efficient synthesis of [2]- and [4]rotaxanes; see: S.Y. Hsueh, K.-W. Cheng, C.-C. Lai, S.-H. Chiu, Angew. Chem. 2008, 120, 4508-4511; Angew. Chem. Int. Ed. 2008, 47, 44364439.

[10] For the possible mechanism of this reaction, see: M. D. Helm, J. E. Moore, A. Plant, J. P. A. Harrity, Angew. Chem. 2005, 117, 
3957-3960; Angew. Chem. Int. Ed. 2005, 44, 3889-3892, and ref. [5].

[11] CCDC 692638 contains the supplementary crystallographic data for this paper. These data can be obtained free of charge from The Cambridge Crystallographic Data Centre via www.ccdc. cam.ac.uk/data_request/cif.

[12] Crystal data for $\left[2-\mathrm{H} \cdot \mathrm{BF}_{4}\right]:\left[\mathrm{C}_{24} \mathrm{H}_{40} \mathrm{O}_{7} \mathrm{~N}_{5}\right]\left[\mathrm{BF}_{4}\right] ; M_{\mathrm{r}}=597.42$; triclinic; space group $\mathrm{P} \overline{1} ; a=15.8676(12) ; b=16.8825(12) ; c=$ $22.8223(16) \AA ; V=5987.7(7) \AA^{3} ; \rho_{\text {calcd }}=1.325 \mathrm{~g} \mathrm{~cm}^{-3} ; \mu\left(\mathrm{Mo}_{\mathrm{K} \alpha}\right)=$ $0.963 \mathrm{~mm}^{-1} ; T=250(2) \mathrm{K}$; colorless cubes; 21316 independent measured reflections; $F^{2}$ refinement; $R_{1}=0.0923 ; w R_{2}=0.2292$.

[13] a) B. Odell, M. V. Reddington, A. M. Z. Slawin, N. Spencer, J. F. Stoddart, D. J. Williams, Angew. Chem. 1988, 100, 1605-1608; Angew. Chem. Int. Ed. Engl. 1988, 27, 1547-1550; b) R. A. Bissell, E. Cordova, A. E. Kaifer, J. F. Stoddart, Nature 1994, 369, $133-137$; c) O. S. Miljanic, J. F. Stoddart, Proc. Natl. Acad. Sci. USA 2007, 104, 12966-12970.

[14] a) A. G. Johnston, D. A. Leigh, A. Murphy, J. P. Smart, M. D. Deegan, J. Am. Chem. Soc. 1996, 118, 10662-10663; b) W. Clegg, C. Gimenez-Saiz, D. A. Leigh, A. Murphy, A. M. Z.
Slawin, S. J. Teat, J. Am. Chem. Soc. 1999, 121, 4124-4129; c) E. R. Kay, D. A. Leigh, Pure Appl. Chem. 2008, 80, 17-29.

[15] a) S. J. Loeb, J. A. Wisner, Chem. Commun. 1998, 2757-2758; b) D. J. Hoffart, S. J. Loeb, Angew. Chem. 2005, 117, 923-926; Angew. Chem. Int. Ed. 2005, 44, 901-904; c) S. J. Vella, J. Tiburcio, S. J. Loeb, Chem. Commun. 2007, 4752-4754.

[16] a) P.-N. Cheng, C.-F. Lin, Y.-H. Liu, C.-C. Lai, S.-M. Peng, S.-H. Chiu, Org. Lett. 2006, 8, 435-438; b) Y.-L. Huang, C.-F. Lin, P.N. Cheng, C.-C. Lai, Y.-H. Liu, S.-M. Peng, S.-H. Chiu, Tetrahedron Lett. 2008, 49, 1665-1669; c) N.-C. Chen, C.-C. Lai, Y.-H. Liu, S.-M. Peng, S.-H. Chiu, Chem. Eur. J. 2008, 14, 2904-2908.

[17] It has been suggested that an alkyl chain might be capable of threading through bis( $m$-phenylene)[20]crown-6 (a 20-membered ring macrocycle); see: a) H. W. Gibson, D. S. Nagvekar, N. Yamaguchi, S. Bhattarcharjee, H. Wang, M. Vergne, D. M. Hercules, Macromolecules 2004, 37, 7514-7529; b) Ref. [4]; note, however, that this macrocycle is heavier and comprises more atoms than $21 \mathrm{C} 7$. 